Available online at: https://proceeding.researchsynergypress.com/index.php/rsfconferenceseries1

RSF Conference Series: Business, Management and Social Sciences

e-ISSN 2807-5803/ p-ISSN 2807-6699

Volume 1 Number 3 (2021): 365-374

\title{
Challenges of Adopting Technological Innovations in Start-Up SMEs in Sleman
}

\author{
Agus Sukarno1, Yuni Istanto1, Gunawan Nusanto², Iwan Kresna Setiadi', Nuruni Ika \\ Kusuma Wardani ${ }^{1}$ \\ 1Department of Management, Universitas Pembangunan Nasional "Veteran" Yogyakarta, Indonesia \\ 2Department of Mining Engineering, Universitas Pembangunan Nasional "Veteran” Yogyakarta, \\ Indonesia
}

\begin{abstract}
The Covid-19 pandemic has destroyed many SMEs throughout Indonesia, even in Sleman. This study aims to test the product innovation model on start-up SMEs in Sleman in overcoming the challenges of digital transformation. The technology analyzed in this study is digital technology in start-up SMEs for product marketing and creating new innovative products. The population in this study were all start-up SMEs in Sleman. Sampling using purposive sampling. The number of samples in this study was 75 respondents. This study uses a respondent survey approach. The data analysis technique used qualitative and quantitative analysis. Qualitative analysis was conducted to create a cluster map of the distribution of startups and technology clusters used by start-ups in Sleman. Quantitative analysis is used to test the product innovation model at start-ups in Sleman.
\end{abstract}

Keywords: technological competence, political competence, prior start-up experience

This is an open access article under the CC-BY-NC license

\section{INTRODUCTION}

Industry 4.0 is faced with various challenges of sustainable development. Extremist advancement is expected to discover new advances, items, and administrations that can address social, ecological, and monetary issues both locally and internationally (Hockerts and Wüstenhagen, 2010). The manageability of social business ventures has additionally been perceived as a driver of the maintainability progress (Bansal, Garg and Sharma, 2019; Terán-Yépez et al., 2020). New company's practical are relied upon to be more creative and more dependable in their way to deal with supportability (Hockerts \& Wüstenhagen, 2010). New companies economical should likewise conquer the difficulties of building and overseeing associations with various accomplices (suppliers, customers, investors, and policymakers).

Sleman is an ideal city to start a start-up or internet-based start-up. In this city, there is a supporting ecosystem that can make digital start-ups thrive, such as creative SMEs, co-working spaces, and business incubators. Unfortunately, many creative SMEs in Sleman is still dominated by rural SMEs that still operate traditionally. The many obstacles and obstacles in digital transformation make this research important to be carried out in order to analyze and provide a solution for the problem of digital adoption in SMEs startup in Sleman.

According to Barile et al. (2020), social/maintainable development is a cycle including various fields (technology, human, social, relational, and cultural). Supportability is dispersed across all unique Corresponding author Agus Sukarno, agus_sukarno@upnyk.ac.id DOI: https://doi.org/10.31098/bmss.v1i3.349 
situations (miniature, meso, and full scale) and requires incorporation through essential administration of shared worth creation, assisting SMEs with accomplishing manageability in the long haul. At the degree of meso investigation, the job of money that upholds the framework is vital. Trouble for a start-up to get financing is a significant issue according to the monetary advancement of non-industrial nations (RibeiroSoriano \& Piñeiro-Chousa, 2021). As the key financing channel for start-ups, easygoing financing is a wellknown subject in both speculative and sober-minded circles (Matsuzaki et al., 2020).

Prior start-up experience is characterized as past experience that a beginning up has had and assumes a significant part in decreasing the negligible expenses related to expanding the degree of utilization of new advances to make new item developments (Deligianni et al., 2019). Start-ups with high introductory experience might have taken in examples from past triumphs as well as disappointments (Politis, 2008). They show more grounded exploratory capacities and consequently can discover different freedoms with a higher likelihood (Dencker \& Gruber, 2015).

\section{LITERATURE REVIEW}

\section{Technology Innovation}

Barile et al. (2020) state that economic advancement is a cycle that includes various fields (technology, human, social, relational, and cultural). Manageability across all settings requires combination through essential administration of shared worth creation, assisting associations with accomplishing long haul supportability. Instances of mechanical advancement incorporate the presentation of new items and gadgets, the presentation of new creative strategies, and the formation of new types of hierarchical cycles (Choi et al., 2020). Creation of products and services with technology (Candi, \& Saemundsson, 2011). Item Advancement or item development mirrors the degree to which organizations create and present new items (Atuahene-Gima, 2005).

\section{Technological Competence}

Interest in mechanical ability is fundamental for the amassing of information that works with the age and double-dealing of development openings and shapes the capability of NTBF to prevail in advancement (Martin-Rojas et al., 2017). With mechanical ability, associations can discover uncommon development openings through innovative ability and logical greatness (Martin-Rojas et al., 2013). Mechanical ability can likewise be basic for the double-dealing of advancement openings, creations that would not be productive without them (Shane \& Venkataraman, 2000). New innovation item dispatches require the coordination of assets both inside and past hierarchical/organization limits (Symeonidou \& Nicolaou, 2017). In any case, low to direct utilization of new innovation in associations can aggregate information (Wang et al., 2004) and detect innovation opportunities to create new products. Doing as such builds adaptability, which can be advantageous (Brush et al., 2001). Advantages incorporate having the option to more readily manage interior asset failures by overseeing cooperation, gaining one-of-a-kind assets and abilities that are fundamental for taking advantage of development openings (Baert et al., 2016). H1: Technological Competence affects Product Innovation

\section{Political Competence}

The use of technology is very important for the innovation and economic growth of a country (Ribeiro-Soriano \& Piñeiro-Chousa, 2021). Political competence reflects the start-up's ability to form, select, manage and exploit diversity. Partnerships (Baron and Tang, 2009; Chandler and Jansen, 1992) can serve to reduce the immaterial costs coming from growing degrees of inventive capacity severally. The 
political ability works with the development of expansive organizations that might include different asset suppliers, for example, innovation accomplices and key clients. Such organizations can give the possibility to get to different significant resources like monetary assets, mechanical ability, dissemination channels, etc. (Semrau \& Sigmund, 2012). Political capability is likewise significant for the choice of the right accomplices and the foundation of solid, beneficial, and logically proper organization connections (Todd et al., 2009). In addition to the use of new technologies for new innovative products with an important set of external resources, the relationship involves a higher frequency of interaction between partners. In this way, empowering the advancement of shared schedules and making asset trade more productive (Semrau and Sigmund, 2012).

H2: Political competence affects Product Innovation

\section{Prior Star-Up Experience}

Earlier beginning up experience or past experience moved by star-up, giving "abilities, information, and experience that empower an individual to deal with troublesome and complex assignments" (Newbert et al. al., 2007), worked by various organizations in which the new companies had partaken at the hour of their foundation as originators or authors (not representatives). The related knowledge moved by star-up can assume a significant part in diminishing the peripheral expenses related to expanding levels of mechanical capability (Deligianni et al., 2019). In the first place, star-up with huge introductory experience is bound to have created abilities, which empower them to adjust in an asset-restricted climate and face the difficulties innate in such circumstances. Second, the past experience of the beginning up permits the past experience of the beginning up to accomplish a more prominent assimilation limit as it gives them "a recognizable hall for extra information, abilities, and capacities identified with big business creation (Baum et al., 2014). Third, star-up with high beginning experience realize how to improve their venture and grow their organization assets, exploit the social ties of their initial inclusion before (Farmer et al., 2011) and utilize external resources. Fourth, the past experience of star-up assumes a part in expanding comprehension and capacity to react to the market (Newbert et al., 2007).

H3: Prior Start-up Experience has an effect on Product Innovation

\section{RESEARCH METHOD}

In view of the exploration destinations, this research is a to test hypotheses. According to Sekaran and Bougie (2016), theory testing is research that clarifies the connection between the reliant and autonomous factors or different factors that impact one variable to another. The population in this study were all SMEs start-ups in Sleman, Yogyakarta, Indonesia. The sampling technique used a non-probability technique with the census method or total sampling, namely a number of 75SMEs start-up in Sleman, Yogyakarta Special Region, Indonesia, as respondents.

\section{Attribute of Respondents}

The attribute of the respondents is showing in Table 1. Most of the respondents are owners and managers of SMEs.

Table 1. Attribute of respondents

\begin{tabular}{|l|c|}
\hline \multicolumn{1}{|c|}{ Attribute } & \% \\
\hline Position: & 25 \\
Manager & 20 \\
Owner & 35 \\
Owner and Manager & \\
\hline
\end{tabular}




\begin{tabular}{|c|c|}
\hline $\begin{array}{l}\text { Length of operation: } \\
\leq 5 \text { years } \\
\geq 5 \text { years }\end{array}$ & $\begin{array}{l}60 \\
15\end{array}$ \\
\hline $\begin{array}{l}\text { Last education: } \\
\text { Elementary/junior high school } \\
\text { Diploma/Bachelor }\end{array}$ & $\begin{array}{l}36 \\
39\end{array}$ \\
\hline $\begin{array}{l}\text { The number of employees: } \\
1-4 \text { people } \\
5-10 \text { people } \\
11-19 \text { people } \\
20-30 \text { people }\end{array}$ & $\begin{array}{l}23 \\
30 \\
12 \\
10\end{array}$ \\
\hline \begin{tabular}{|l|} 
Average turnover per year: \\
1 million to 50 million \\
50 million to 300 million \\
300 million to 500 million \\
500 million to 2.5 billion \\
\end{tabular} & $\begin{array}{l}21 \\
34 \\
11 \\
10 \\
\end{array}$ \\
\hline $\begin{array}{l}\text { Length of time to adopt technology / e-commerce } \\
\text { / social media: } \\
1-12 \text { months } \\
1-3 \text { years } \\
\geq 3 \text { years }\end{array}$ & $\begin{array}{c}9 \\
11 \\
55\end{array}$ \\
\hline
\end{tabular}

\section{Reliability and Validity}

The analytical technique used in this study is Partial Least Square (PLS). According to (Hair et al., 2014), PLS is one of the Structural Equation Modeling (SEM) techniques that can directly analyze latent variables, indicator variables, and measurement errors. PLS can be used with small sample sizes and can be applied to all data scales. The outer model or test of reflective indicators is evaluated through convergent validity, discriminant validity, and AVE. Meanwhile, the reliability test is seen from the composite reliability and Cronbach alpha values. Valid and reliable data is $>0.7$, and the expected AVE value is $>0.5$; each construct shown in table $1 \&$ table 2 has criteria above the expected standard.

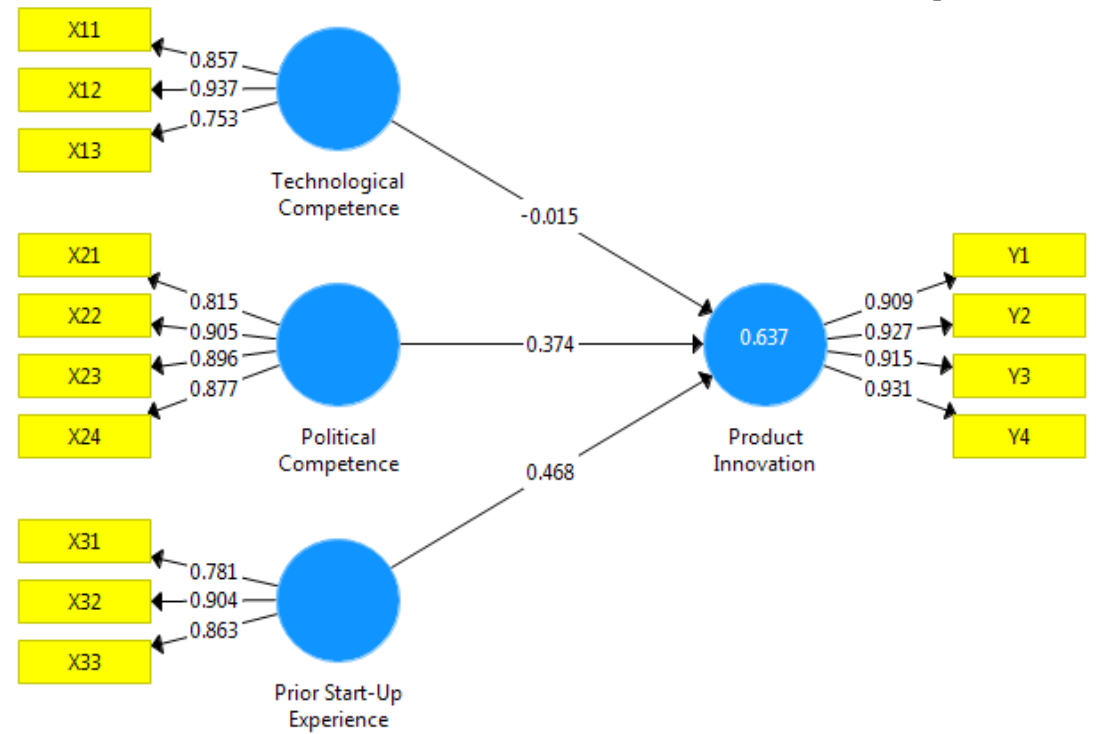

Figure 1. Results of Testing Model Algorithm 
RSF Conference Series: Business, Management and Social Sciences, Vol. 1 (3), 365-374

Challenges of Adopting Technological Innovations in Start-Up SMEs in Sleman

Agus Sukarno, Yuni Istanto, Gunawan Nusanto, Iwan Kresna Setiadi, Nuruni Ika Kusuma Wardani

Table 2. Contruct Reliability and Validity

\begin{tabular}{|c|c|c|c|c|c|}
\hline Latent Variable & $\begin{array}{l}\text { Measurement } \\
\text { Item }\end{array}$ & $\begin{array}{c}\text { Outer } \\
\text { Loading }\end{array}$ & $\begin{array}{c}\text { Cronbach's } \\
\text { Alpha }\end{array}$ & $\begin{array}{l}\text { Composite } \\
\text { Reliability }\end{array}$ & $\begin{array}{c}\text { Average } \\
\text { Variance } \\
\text { Extracted } \\
\text { (AVE) }\end{array}$ \\
\hline \multirow{3}{*}{$\begin{array}{c}\text { Technological } \\
\text { Competence }\end{array}$} & X11 & 0.857 & \multirow[t]{3}{*}{0.809} & \multirow[t]{3}{*}{0.888} & \multirow[t]{3}{*}{0.726} \\
\hline & X12 & 0.937 & & & \\
\hline & $\begin{array}{l}\mathbf{X 1 3} \\
\end{array}$ & 0.753 & & & \\
\hline \multirow{4}{*}{$\begin{array}{c}\text { Political } \\
\text { Competence }\end{array}$} & $\mathrm{X21}$ & 0.815 & \multirow[t]{4}{*}{0.897} & \multirow[t]{4}{*}{0.928} & \multirow[t]{4}{*}{0.764} \\
\hline & $\mathrm{X} 22$ & 0.905 & & & \\
\hline & $\mathrm{X} 23$ & 0.896 & & & \\
\hline & X24 & 0.877 & & & \\
\hline \multirow{3}{*}{$\begin{array}{c}\text { Prior Start-Up } \\
\text { Experience }\end{array}$} & X31 & 0.781 & \multirow[t]{3}{*}{0.808} & \multirow[t]{3}{*}{0.887} & \multirow[t]{3}{*}{0.724} \\
\hline & X32 & 0.904 & & & \\
\hline & X33 & 0.863 & & & \\
\hline \multirow{4}{*}{$\begin{array}{l}\text { Product } \\
\text { Innovation }\end{array}$} & Y1 & 0.909 & \multirow[t]{4}{*}{0.940} & \multirow[t]{4}{*}{0.957} & \multirow[t]{4}{*}{0.847} \\
\hline & Y2 & 0.927 & & & \\
\hline & Y3 & 0.915 & & & \\
\hline & Y4 & 0.931 & & & \\
\hline
\end{tabular}

Table 3. Cross Loading

\begin{tabular}{|l|c|c|c|c|}
\hline & $\begin{array}{c}\text { Political } \\
\text { Competence }\end{array}$ & $\begin{array}{c}\text { Prior Start-Up } \\
\text { Experience }\end{array}$ & $\begin{array}{c}\text { Product } \\
\text { Innovation }\end{array}$ & $\begin{array}{c}\text { Technological } \\
\text { Competence }\end{array}$ \\
\hline $\mathbf{X 1 1}$ & 0,728 & 0,671 & 0,631 & $\mathbf{0 , 8 5 7}$ \\
\hline $\mathbf{X 1 2}$ & 0,849 & 0,813 & 0,662 & $\mathbf{0 , 9 3 7}$ \\
\hline $\mathbf{X 1 3}$ & 0,621 & 0,657 & 0,481 & $\mathbf{0 , 7 5 3}$ \\
\hline $\mathbf{X 2 1}$ & $\mathbf{0 , 8 1 5}$ & 0,675 & 0,567 & 0,690 \\
\hline $\mathbf{X 2 2}$ & $\mathbf{0 , 9 0 5}$ & 0,811 & 0,665 & 0,807 \\
\hline $\mathbf{X 2 3}$ & $\mathbf{0 , 8 9 6}$ & 0,785 & 0,686 & 0,752 \\
\hline $\mathbf{X 2 4}$ & $\mathbf{0 , 8 7 7}$ & $\mathbf{0 , 7 2 4}$ & 0,729 & 0,775 \\
\hline $\mathbf{X 3 1}$ & 0,671 & $\mathbf{0 , 7 8 1}$ & 0,603 & 0,634 \\
\hline $\mathbf{X 3 2}$ & 0,786 & $\mathbf{0 , 9 0 4}$ & 0,646 & 0,763 \\
\hline $\mathbf{X 3 3}$ & 0,729 & $\mathbf{0 , 8 6 3}$ & 0,721 & 0,738 \\
\hline Y1 & 0,679 & 0,716 & $\mathbf{0 , 9 0 9}$ & 0,653 \\
\hline Y2 & 0,716 & 0,710 & $\mathbf{0 , 9 2 7}$ & 0,633 \\
\hline Y3 & 0,607 & 0,673 & $\mathbf{0 , 9 1 5}$ & 0,592 \\
\hline Y4 & 0,787 & 0,751 & $\mathbf{0 , 9 3 1}$ & 0,695 \\
\hline
\end{tabular}




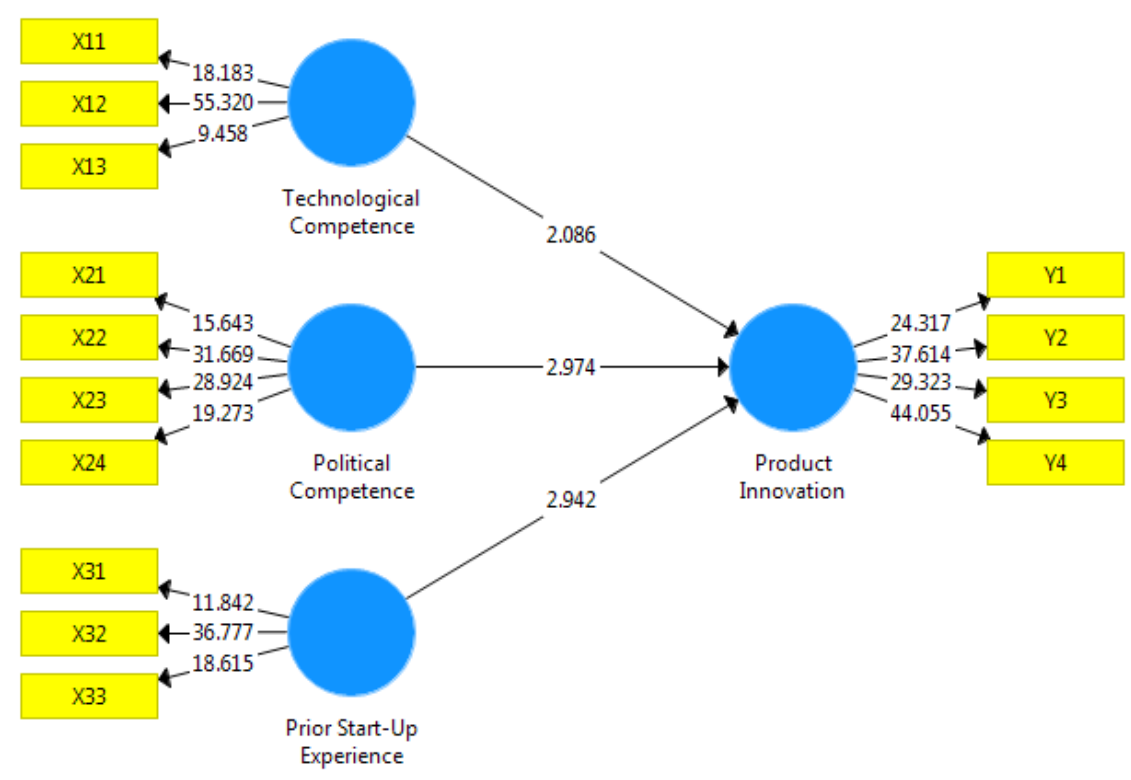

Figure 2. bootstrapping Model Testing Results

Table 4. Mean, STDEV, T-Values, P-Values

\begin{tabular}{|l|c|c|c|c|c|}
\hline & $\begin{array}{c}\text { Original } \\
\text { Sample } \\
\text { (O) }\end{array}$ & $\begin{array}{c}\text { Sample } \\
\text { Mean } \\
\text { (M) }\end{array}$ & $\begin{array}{c}\text { Standard Deviation } \\
\text { (STDEV) }\end{array}$ & $\begin{array}{c}\text { T Statistics } \\
(\mid \text { OOSTDEV|) }\end{array}$ & $\begin{array}{c}\text { Palue } \\
\text { V }\end{array}$ \\
\hline $\begin{array}{l}\text { Technological Competence ? } \\
\text { Product Innovation }\end{array}$ & $-0,015$ & 0,025 & 0,173 & 0,086 & 0,931 \\
\hline $\begin{array}{l}\text { Political Competence ? Product } \\
\text { Innovation }\end{array}$ & 0,374 & 0,356 & 0,126 & 2,974 & 0,003 \\
\hline $\begin{array}{l}\text { Prior Start-Up Experience ? } \\
\text { Product Innovation }\end{array}$ & 0,468 & 0,448 & 0,159 & 2,942 & 0,003 \\
\hline
\end{tabular}

The results of quantitative analysis in this study showed that all hypotheses of a positive and significant effect. The original sample value in $\mathrm{H} 1(-0.015)$ has a negative value which indicates a negative relationship. Meanwhile, $\mathrm{H} 2(0.374)$ and $\mathrm{H} 3(0.468)$ have a positive value, so that it shows a positive relationship. On the other hand, the value of $t$ statistics has numbers $>1.960$ and $p$-values $>5 \%$, except for $\mathrm{H} 1$. This means that the hypothesis H1 ( $\mathrm{t}$-value $=0.086 / \mathrm{p}$-value $=0.931$ ) is not supported, while H2 $(\mathrm{t}$ value $=2.974 / \mathrm{p}$-value $=0.003$ ), and H3 (t-value $=2.942 / \mathrm{p}$-value $=0.003$ ) is supported.

\section{FINDINGS AND DISCUSSION}

The hypothesis in this study has a positive and significant relationship except for the hypothesis of technological competence on product innovation. This is as stated by Deligianni et al.(2019), who contend that at more elevated levels of mechanical ability, negligible expenses will in general increment quickly and are probably going to surpass benefits, with the arrival of innovative capability on development turning out to be progressively negative. For this situation, this concentrate additionally tracked down a negative connection between mechanical ability and item advancement. Symeonidou and Nicolaou (2017) additionally say that mechanical ability, high interest in innovative skills can control interest in different assets and capacities. Launching a new technology product requires managing resources both within and 
outside the firm's boundaries, which may be difficult for companies to fund one type of resource over another (Symeonidou and Nicolaou, 2017; Wales et al., 2013). Thus, it can be said that SMEs start-up in Sleman, Yogyakarta, Indonesia have technological competence, which actually has a negative effect on product innovation. Subsequently, the degree of mechanical skill of start-up SMEs in Sleman should be offset with the degree of proficiency in overseeing mechanical and non-mechanical assets and using the capacity to develop on item advancement. Furthermore, by showing that pioneering ability supports the beneficial outcome of mechanical skill on advancement, this review affirms the job of innovative characteristics in deciding assets and capacities in new businesses, adding to a comprehension of the 'miniature establishments' of asset arrangement (Symeonidou and Nicolaou, 2017).

It also increases understanding of the role of entrepreneur capabilities in influencing new venture outcomes (e.g., Dencker and Gruber, 2015). Consequently, business people ought to know about the limits related to a degree of mechanical ability past that, which might trap them in the continuous area of mechanical movement, keeping them from zeroing in on advancements with a higher likelihood of progress. To address such difficulties, business visionaries additionally need to foster comprehension of their capability to enhance the advantages of taking advantage of their innovative skills. As a component of this arrangement, they need to perceive their own shortcomings and qualities and further develop their own skill, which will further develop the asset coordination capacity of their business.

\section{CONCLUSION AND FUTURE RESEARCH}

Because of restricted assets, SMEs fire up in Sleman in their endeavors towards advancement need to painstakingly gauge the advantages related to putting resources into innovative and non-mechanical assets and capacities. As such ventures might be costly, hazardous, and tedious, approach mediation will be essential. A significant job for strategy creators is to figure proper approaches with respect to enterprising abilities and innovation capability advancement. The approach isn't just to help business arrangement and improvement of Research and development exercises, yet additionally to empower instruction and prepare for the advancement of enterprising capabilities. One more space of help is to upgrade the political capability of businesspeople by supporting them to make and use fitting organization connections that will fill in as a course for the exchange of information and skills needed for fruitful development.

\section{Suggestions for Further Research}

The discoveries of this review might have significant reasonable ramifications for business visionaries and administrators. Reviewing the restricted interest in their neighborhood market and the emergence of a crisis, start-ups often need to transform into a global market. Economical new businesses are relied upon to fabricate solid community-oriented connections around advancement, business, and monetary biological systems and drive institutional change towards supportable models dependent on round economies or option-related ideas (Narvanen et al., 2020).

Although this study is in line with some previous researchers, it still needs to be evaluated against the limitations of the study. The main restriction concerns the chance of public predisposition as the information comes from one area/district, which might introduce explicit attributes of innovative conduct. The future examination could likewise analyze whether comparable examples of advancement exist between locales or districts with tantamount qualities. Second, because of the absence of target information estimating imaginative execution, this review depended on a wide scope of respondents who might have been influenced by issues related to normal source predisposition. Albeit the tests utilized 
recommend that a particular inclination may not exist, future exploration utilizing an alternate report configuration could address this predisposition. Finally, albeit key business people are viewed as the concentration and assume a significant part in their corporate exercises (Lechler, 2001). Future exploration can look at the impact of pioneering groups on the connection between innovation advancement competencies expansion, supportable improvement requires activity from every single monetary entertainer and from a wide range of ventures and requires customary endeavors to foster revolutionary developments in items, administrations, and plans of action. Hence, it is additionally intriguing to investigate how these organizations can profit from applying early deduction in their constant advancement measures (Weissbrod \& Bocken, 2017).

\section{REFERENCES}

Atuahene-Gima, K. (2005). Resolving the Capability-Rigidity Paradox in New Product Innovation. Journal of Marketing, 69(4), 61-83. https://doi.org/10.1509/jmkg.2005.69.4.61.

Baert, C., Meuleman, M., Debruyne, M. (2016). Portfolio entrepreneurship and resource orchestration. Strat. Entrepr. J. https://doi.org/10.1002/sej.

Bansal, S., Garg, I. and Sharma, G. D. (2019) 'Social entrepreneurship as a path for social change and driver of sustainable development: A systematic review and research agenda', Sustainability (Switzerland), 11(4). doi: 10.3390/SU11041091.

Baron, R.M., Tang, J. (2009). 'Entrepreneurs' social skills and new venture performance: mediating mechanisms and cultural generality'. J. Manag. 35 (2), 282-306. https://doi.org/10.1177/0149206307312513

Baum, J. R., Frese, M., \& Baron, R. A. (Eds.). (2014). The psychology of entrepreneurship. Psychology Press.

Brush, C. G., Greene, P. G., \& Hart, M. M. (2001). From initial idea to unique advantage: The entrepreneurial challenge of constructing a resource base. AMP, 15, 64-78. https://doi.org/10.5465/ame.2001.4251394.

Candi, M., \& Saemundsson, R. (2011). Exploring the relationship between aesthetic design as an element of new service development and performance. J. Prod. Innov. Manag. 28, 536-557.

Chandler, G. N., \& Hanks, S. H. (1998). An examination of the substitutability of founders human and financial capital in emerging business ventures. Journal of business venturing, 13(5), 353-369. https://doi.org/10.1016/S0883-9026(97)00034-7.

Choi, D. S., Sung, C.S., Park, J. Y. (2020). How Does Technology Startups Increase Innovative Performance? The Study of Technology Startups on Innovation Focusing on Employment Change in Korea. Sustainability, 12(2), 551. https://doi.org/10.3390/su12020551.

Deligianni, I., Voudouris, I., Spanos, Y., Lioukas. S. (2019). Non-linear effects of technological competence on product innovation in new technology-based firms: Resource orchestration and the role of the entrepreneur's political competence and prior start-up experience. Technovation, 88. https://doi.org/10.1016/j.technovation.2019.05.002.

Dencker, J.C. \& Gruber, M. (2015), The effects of opportunities and founder experience on new firm performance. Strat. Mgmt. J., 36: 1035-1052. https://doi.org/10.1002/smj.2269.

Farmer, S. M., Yao, X., \& Kung-Mcintyre, K. (2011). The Behavioral Impact of Entrepreneur Identity Aspiration and Prior Entrepreneurial Experience. Entrepreneurship Theory and Practice, 35(2), 245-273. https://doi.org/10.1111/j.1540-6520.2009.00358.x 
Hair, J. et al. (2014) A Primer on Partial Least Squares Structural Equation Modeling (PLS-SEM). California. USA: SAGE Publications, Inc.

Hockerts, K. and Wüstenhagen, R. (2010) 'Greening Goliaths versus emerging Davids — Theorizing about the role of incumbents and new entrants in sustainable entrepreneurship', Journal of Business Venturing, 25(5), pp. 481-492. doi: 10.1016/J.JBUSVENT.2009.07.005.

Lechler, T. Social Interaction: A Determinant of Entrepreneurial Team Venture Success. Small Business Economics 16, 263-278 (2001). https://doi.org/10.1023/A:1011167519304

Martín-Rojas, R., Fernández-Pérez, V., \& García-Sánchez, E. (2017). Encouraging organizational performance through the influence of technological distinctive competencies on components of corporate entrepreneurship. Int Entrep Manag J, 13, 397-426. https://doi.org/10.1007/s11365-016-0406-7.

Martín-Rojas, R., García-Morales, V. J., \& Bolívar-Ramos, M. T. (2013). Influence of technological support, skills and competencies, and learning on corporate entrepreneurship in European technology firms. Technovation, 33(12), 417-430. https://doi.org/10.1016/j.technovation.2013.08.002.

Matsuzaki, Taisuke \& Shigeno, Hidenori \& Ueki, Yasushi \& Tsuji, Masatsugu. (2020). Innovation upgrading of local small and medium-sized enterprises and regional innovation policy: An empirical study. Industrial Marketing Management. https://doi.org/10.1016/j.indmarman.2020.07.009.

Narv̈anen, E., Mattila, M., \& Mesiranta, N. (2020). Institutional work in food waste reduction: Startups' role in moving towards a circular economy. Industrial Marketing Management. https://doi.org/10.1016/j.indmarman.2020.08.009

Newbert, S.L., Kirchhoff, B.A., Walsh, S.T. (2007). Defining the relationship among founding resources, strategies and performance in technology intensive new ventures: evidence from the semiconductor silicon industry. J. Small Bus. Manag. 45(4), 438-466. https://doi.org/10.1111/j.1540627X.2007.00222.x.

Politis, D. (2008). Does prior start-up experience matter for entrepreneurs' learning? A comparison between novice and habitual entrepreneurs. Journal of Small Business and Enterprise Development, 15 (3), 472-489. https://doi.org/10.1108/14626000810892292.

Ribeiro-Soriano, D., Piñeiro-Chousa, J. (2021). Innovative strategic relationships among sustainable start-ups. Industrial Marketing Management. https://doi.org/10.1016/j.indmarman.2021.01.008

Shane, S., Venkataraman, S. (2000). The promise of entrepreneurship as a field of research. Acad. Manag. Rev. 25 (1), 217-226.

Semrau, T., Sigmund, S. (2012). Networking ability and the financial performance of new ventures: a mediation analysis among younger and more mature firms. Strat. Entrepren. J. 6 (4), 335-354.

Symeonidou, N., Nicolaou, N. (2017). Resource orchestration in start-ups: synchronizing human capital investment, leveraging strategy and founder start-up experience. Strat. Entrepr. J.https://doi.org/10.1002/sej.1269.

Terán-Yépez, E. et al. (2020) 'Sustainable entrepreneurship: Review of its evolution and new trends', Journal of Cleaner Production, 252, p. 119742. doi: 10.1016/J.JCLEPRO.2019.119742.

Todd, S.Y., Harris, K.J., Harris, R.B., Wheeler, A.R. (2009). Career success implications of political skill. J. Social Psych. 149 (3), 279-304. https://doi.org/10.3200/SOCP.149.3.279-304.

Wang, Y., Lo, H.-P., Yang, Y. (2004). The constituents of core competencies and firm performance: evidence from high-technology firms in China. J. Eng. Technol. Manag. 21 (4), 249-280. https://doi.org/10.1016/j.jengtecman.2004.09.001. 
RSF Conference Series: Business, Management and Social Sciences, Vol. 1 (3), 365-374

Challenges of Adopting Technological Innovations in Start-Up SMEs in Sleman

Agus Sukarno, Yuni Istanto, Gunawan Nusanto, Iwan Kresna Setiadi, Nuruni Ika Kusuma Wardani

Weissbrod, I., \& Bocken, N. M. P. (2017). Developing sustainable business experimentation capability - A case study. Journal of Cleaner Production, 142, 2663-2676. https://doi.org/10.1016/j.jclepro.2016.11.009. 